\title{
Academic partnerships 2015
}

\section{Brady Huggett}

The number of disclosed preclinical partnerships (excluding straight licensing deals) for academic institutions in 2015 was similar to 2014's (236 versus 237 deals) but 150 fewer than in 2012, when deal making was at its peak. Since then, the availability of partnering money has decreased, and consortia have become less popular. Similar to last

year, Texas's and California's expansive public university systems dominate this list (Table 1), with the former replacing the latter at the top. The most active pharma or big biotech in deal making was GlaxoSmithKline with 9 public deals (Fig. 1); AstraZeneca, which recorded 18 deals in 2014, added another seven in 2015.

\begin{tabular}{|c|c|c|}
\hline University & Partners & Terms \\
\hline \multirow[t]{9}{*}{$\begin{array}{l}\text { University of Texas (12 } \\
\text { deals) }\end{array}$} & $\begin{array}{l}\text { MD Anderson Cancer Center (MDACC), } \\
\text { Adimab }\end{array}$ & Antibody discovery collaboration with Adimab \\
\hline & MDACC, CytomX Therapeutics & Research Probody-enabled chimeric antigen receptor (CAR) natural killer cell therapies \\
\hline & MDACC, Theraclone Sciences & Launched OncoResponse, an immuno-oncology antibody discovery company \\
\hline & MDACC, Cellectis & Develop cellular immunotherapies against different types of liquid tumors \\
\hline & MDACC, HTG Molecular Diagnostics & Two-year sponsored research agreement on gene expression assays \\
\hline & MDACC, Astellas Pharma & Collaboration on h8F4 technology, a humanized monoclonal antibody \\
\hline & MDACC, NanoString & Develop assay based on NanoString's nCounter Analysis System, in part for immuno-oncology \\
\hline & MDACC, Amgen & Evaluate Amgen's bispecific T-cell engager (BiTE) antibody constructs \\
\hline & $\begin{array}{l}\text { MDACC, Intrexon, Ziopharm, University } \\
\text { of Minnesota }\end{array}$ & $\begin{array}{l}\text { Licensing agreement, including intellectual property developed at the University of Minnesota, to } \\
\text { develop nonviral adoptive cellular cancer immunotherapies }\end{array}$ \\
\hline & UC QB3, Calico & Conduct research into longevity and age-related diseases \\
\hline & UC San Diego, GlaxoSmithKline & Collaboration to eradicate cancer stem cells, treat leukemia \\
\hline & UC San Francisco, BioCision & Advance cell therapy for organ transplantation and diabetes \\
\hline & UC San Francisco, Cisco & Develop an interoperability platform for sharing healthcare information \\
\hline & UC San Francisco, SeraCare Life Sciences & License to use trisomy 21 (T21), trisomy 18 (T18) and trisomy 13 (T13) trophoblast cell line material \\
\hline \multirow{4}{*}{$\begin{array}{l}\text { University of } \\
\text { Pennsylvania ( } 4 \text { deals) }\end{array}$} & WuXi NextCODE & Combine Penn's viral vector production with WuXi AppTec \\
\hline & Cypher Genomics & Collaborate on CurePSP-funded study in progressive supranuclear palsy \\
\hline & RegenXBio & $\begin{array}{l}\text { Licensing deal from University of Pennsylvania and University of Minnesota to develop treatments } \\
\text { for mucopolysaccharidosis type I (MPS I) and MPS II }\end{array}$ \\
\hline & PTC Therapeutics & Collaborate on orphan disease research \\
\hline
\end{tabular}

Also with three deals: Johns Hopkins University and University of Southampton. Source: BCIQ: BioCentury Online Intelligence.

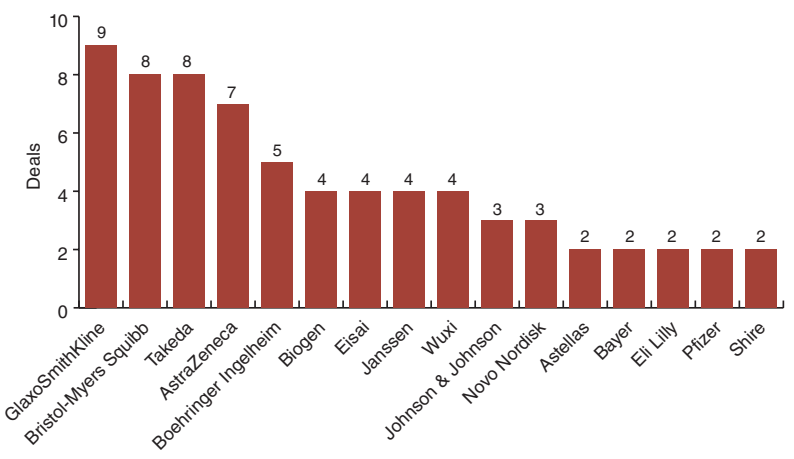

Figure 1 The most-active pharmas and big biotechs with academic or research institute partners.Source: $\mathrm{BCIQ}$ : BioCentury Online Intelligence.

\section{First Rounders Podcast: Daniel Cohen}

Daniel Cohen is chairman and CEO of Pharnext. He was also co-founder of CEPH, Genethon and Millennium, and an early leader in the genomics field. His talk with Nature Biotechnology covers the industrialization of genomic sequencing, his part in founding Millennium and why the conductor has the most difficult job in an orchestra.

http://www.nature.com/nbt/podcast/index.html

Brady Huggett is Business Editor at Nature Biotechnology. 